\title{
Neuropeptide W exerts a potent suppressive effect on blood leptin and insulin concentrations in the rat
}

\author{
MARCIN RUCINSKI ${ }^{1}$, KRZYSZTOF W. NOWAK ${ }^{2}$, JOANNA CHMIELEWSKA ${ }^{2}$, \\ AGNIESZKA ZIOLKOWSKA ${ }^{1}$ and LUDWIK K. MALENDOWICZ ${ }^{1}$ \\ ${ }^{1}$ Department of Histology and Embryology, School of Medicine, Poznan University of Medical Sciences; \\ ${ }^{2}$ Department of Animal Physiology and Biochemistry, August Cieszkowski University of Agriculture, Poznan, Poland
}

Received November 2, 2006; Accepted December 5, 2006

\begin{abstract}
Neuropeptide B/W receptor 1 (NPBWR1) and neuropeptide $\mathrm{B} / \mathrm{W}$ receptor 2 (NPBWR2) are two structurally related orphan receptors linked to protein $\mathrm{G}$. In rodents NPBWR2 is absent, and its counterpart is described as being similar to neuropeptide $\mathrm{B} / \mathrm{W}$ receptor 2 . Endogenous ligands of these receptors have been identified. One of them is 29 amino acid residues long, uniquely modified with bromine and, thus, termed neuropeptide B (NPB). The other, neuropeptide W (NPW), has been identified in two molecular forms of 23 and 30 amino acids (NPW23 and NPW30), respectively. Both NPB and NPW affect food intake and energy expenditure. Since leptin, a potent anti-obesity hormone, and insulin are involved in the control of energy homeostasis, the present study aimed to investigate whether NPB and NPW affect leptin and insulin secretion in the rat. RT-PCR technique revealed the presence of ppNPB, ppNPW, NPBWR1 and NPBWR2-like mRNAs in isolated pancreatic islets of the rat. NPB and NPW immunoreactivities were observed in all of the cells of the pancreatic islets. Only when a higher dose was administered ( $3 \mathrm{nmol} / 100 \mathrm{~g}$ body weight) did NPW transiently lower blood insulin levels whereas NPB injection did not alter insulinaemia in the studied rats. At $30 \mathrm{~min}$, but not 60 , of the experiment, NPW notably lowered blood leptin concentrations at both tested doses. On the contrary, NPB injections had no effect on blood leptin and insulin concentrations. Thus, the results suggest that NPW but not NPB exerts a potent suppressive effect on blood leptin concentrations in the rat, and this mechanism may be involved in NPW regulation of energy homeostasis.
\end{abstract}

Correspondence to: Dr Ludwik K. Malendowicz, Department of Histology and Embryology, School of Medicine, Poznan University of Medical Sciences, 6 Swiecicki St., 60-781 Poznan, Poland E-mail:1km@amp.edu.pl

Key words: neuropeptide B, neuropeptide W, neuropeptide B/W receptor 1, neuropeptide $\mathrm{B} / \mathrm{W}$ receptor 2-like, pancreas, islet, rat, RT-PCR, leptin, insulin

\section{Introduction}

Neuropeptides B (NPB) and W (NPW) have been identified as endogenous ligands of two G-protein-coupled receptors, NPBWR1 (neuropeptide B/W receptor 1 , formerly known as GPR7) and NPBWR2 (neuropeptide B/W receptor 2, formerly known as GPR8). In rodents where NPBWR2 is absent, its counterpart is described as being similar to neuropeptide $\mathrm{B} / \mathrm{W}$ receptor 2 (formerly GPR8-like) (1-3).

NPB is a polypeptide composed of 29 amino acid residues, uniquely modified with bromine. NPW, on the other hand, has been identified in two molecular forms of 23 and 30 amino acids (NPW23 and NPW30) respectively. The amino acid sequence of NPW23 is identical to the first $23 \mathrm{~N}$ terminal amino acids of NPW30 (4,5). Expression of NPB, NPW and their receptor gene was found to be present in the central nervous system and in the peripheral organs of humans, rats, and mice $(1,2,5-9)$. Distribution of the gene expression within the brain suggests that NPB plays a role in the control of feeding and neuroendocrine axis functions, as well as in memory and learning processes. NPW in turn, affects feeding, stimulates prolactin secretion, and regulates the function of the hypothalamic-pituitary-adrenal axis. Intracerebroventricular infusion of NPB or NPW affects food intake and energy expenditure $(5,8,10-12)$. Furthermore, targeted disruption of the NPBWR1 gene leads to metabolic defects and adult-onset obesity (7). Similar effects have been observed in NPB-null mice (13).

Since leptin, a potent anti-obesity hormone is involved in the control of energy homeostasis, the present study aimed to investigate whether NPB and NPW affect leptin secretion in the rat. The results demonstrated a potent suppressive effect of NPW, but not NPB, on leptin and insulin secretion in the rat.

\section{Materials and methods}

Chemicals. NPB29 and NPW23 were purchased from Phoenix Pharmaceuticals (Belmont, CA, USA). Normal goat serum and strept $\mathrm{AB}$ complex/HRP were obtained from Dako (Glostrup, Denmark). If not otherwise stated, the remaining reagents were from Sigma (St. Louis, MO) or POCh (Gliwice, Poland). 
Table I. PCR analysis of NPB, NPW, NPBWR1 and NPBWR2-like mRNA expression in isolated pancreatic islets of the rat.

\begin{tabular}{|c|c|c|c|c|c|}
\hline cDNA & $\begin{array}{c}\text { Genbank } \\
\text { accession no. }\end{array}$ & Primer & Primer sequence $\left(5^{\prime}-3^{\prime}\right)$ & Position & $\begin{array}{c}\text { PCR product } \\
\text { size (bp) }\end{array}$ \\
\hline \multirow[t]{2}{*}{ NPB } & \multirow[t]{2}{*}{ NM 153293} & $\mathrm{~S}$ & CGGGATCCCACCACTACTC & $80-98$ & \multirow[t]{2}{*}{249} \\
\hline & & A & GAAGACGTCCGCCTTACACT & $305-324$ & \\
\hline \multirow[t]{2}{*}{ NPW } & \multirow[t]{2}{*}{ NM 153294} & $\mathrm{~S}$ & ACCTGAGCAGTCGCTAAGCTTT & $489-510$ & \multirow[t]{2}{*}{150} \\
\hline & & A & CATCGGTTCTTGAGACGGTC & $619-638$ & \\
\hline \multirow[t]{2}{*}{ NPBWR1 } & \multirow[t]{2}{*}{ AY 577901} & $\mathrm{~S}$ & CATCTGCGCCCTCTATATCA & $660-679$ & \multirow[t]{2}{*}{218} \\
\hline & & A & GAAGTAAGAGATGCCGATGACC & $858-879$ & \\
\hline \multirow[t]{2}{*}{ NPBWR2-like } & \multirow[t]{2}{*}{ XM 578201} & $\mathrm{~S}$ & CAGCTCTCTTAGCCCAAGTGTAAGG & $24-48$ & \multirow[t]{2}{*}{180} \\
\hline & & A & GTGTCTTCCTCССССTGAATC & $283-203$ & \\
\hline
\end{tabular}

Oligonucleotide sequences for sense (S) and antisense (A) primers are shown.

Animals and tissues. Adult female Wistar rats were kept under a 12/12-h light/dark cycle (illumination onset at 08:00) at $23^{\circ} \mathrm{C}$, and maintained on a standard diet and tap water ad libitum. Rats were decapitated and the pancreases promptly removed under sterile conditions. Fragments of the glands were fixed in Bouin's solution. For RT-PCR studies pancreatic islets were isolated by collagenase digestion (14). The local Ethics Committee for Animal Studies approved the experimental protocol.

In vivo studies. Rats were given daily subcutaneous (s.c.) injections of $0.2 \mathrm{ml} 0.9 \% \mathrm{NaCl}$ for 9 days to dampen injection- and handling-induced stress. On day 10 at time 0 rats received s.c. injections of NPB or NPW at doses of 1 or $3 \mathrm{nmol} / 100 \mathrm{~g}$ body weight while control rats received injections of $0.2 \mathrm{ml}$ of physiologic saline solution.

Rats were decapitated 30 and 60 min after injection (10:00-11:00) and trunk blood was collected in the presence of EDTA $(1 \mathrm{mg} / \mathrm{ml})$. The plasma was separated and stored at $-36^{\circ} \mathrm{C}$ until biochemical testing.

RT-PCR of NPB, NPW, NPBWR1 and NPBWR2-like gene expression. From each tissue sample $(\sim 30 \mathrm{mg})$ total RNA was extracted using an RNeasy mini kit (Qiagen, Hilden, Germany). The amount and quality of the obtained RNA was measured spectrophotometrically and also examined on $1 \%$ agarose gel with ethidium bromide. For cDNA synthesis with AMV polymerase (Qiagen), oligoT was used as a primer. The RT step was performed at $42^{\circ} \mathrm{C}$ for $60 \mathrm{~min}$, and PCR was performed according to procedures described previously (15). PCR consisted of an initial predenaturation step at $94^{\circ} \mathrm{C}$ for $10 \mathrm{~min}$, followed by 34 cycles of denaturation at $94^{\circ} \mathrm{C}$ for $30 \mathrm{sec}$, annealing at $58^{\circ} \mathrm{C}$ for $60 \mathrm{sec}$ and extension at $68^{\circ} \mathrm{C}$ for $120 \mathrm{sec}$. PCR products were examined by electrophoresis on $2 \%$ agarose gel after ethidium bromide staining and compared with DNA ladder (O'RangeRuler 50bp DNA Ladder, MBI Fermentas, Lithuania). As a control, PCR on isolated RNA (-RT) was used. Primer sequences and the predicted size of the PCR products are presented in Table I.
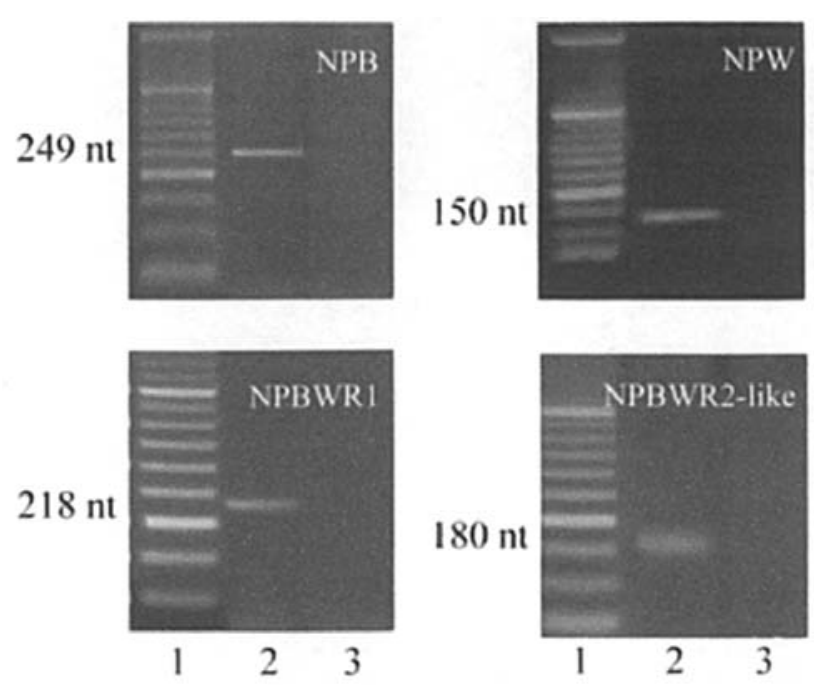

Figure 1. Ethidium bromide-stained $2 \%$ agarose gel showing cDNA amplified with rat NPB, NPW, NPBWR1 and NPBWR2-like-specific primers from RNA of the isolated rat pancreatic islets. Lanes 1 were loaded with 200 ng of DNA-size marker (50-bp DNA ladder; MBI Fermentas, Vilnius, Lithuania). Lanes 2, RT-PCR reactions; lanes 3, control reactions RT. The amplified fragments were of the expected size: NPB, $249 \mathrm{bp}$; NPW, $150 \mathrm{bp}$; NPBWR1, $218 \mathrm{bp}$; and NPBWR2-like, $180 \mathrm{bp}$. No amplification of the PCR mixture without prior RT of the mRNAs is shown as negative control.

Immunocytochemistry (ICC). Bouin's fixed samples were embedded in paraffin and sectioned at $6 \mu \mathrm{m}$. Sections were deparaffinized, and incubated in $3 \% \mathrm{H}_{2} \mathrm{O}_{2}$ for $30 \mathrm{~min}$ at room temperature to block endogenous peroxidase activity. After washing in PBS, sections were preincubated with normal goat serum (Dako) for $30 \mathrm{~min}$ at $37^{\circ} \mathrm{C}$ and subsequently incubated with the primary antibody (rabbit anti-NPB-29 and rabbit anti-NPW-23 antibody, 1:200 dilution), for $1 \mathrm{~h}$ at $4^{\circ} \mathrm{C}$. After a 10-min wash in PBS, sections were incubated with the secondary antibody (Dako, Strept AB complex/HRP, 1:100 dilution) for $60 \mathrm{~min}$ at $37^{\circ} \mathrm{C}$. After washing in PBS, sections were incubated with secondary antibody and peroxidase (Dako, LSAB 2 system HRP, code no. K0609). 


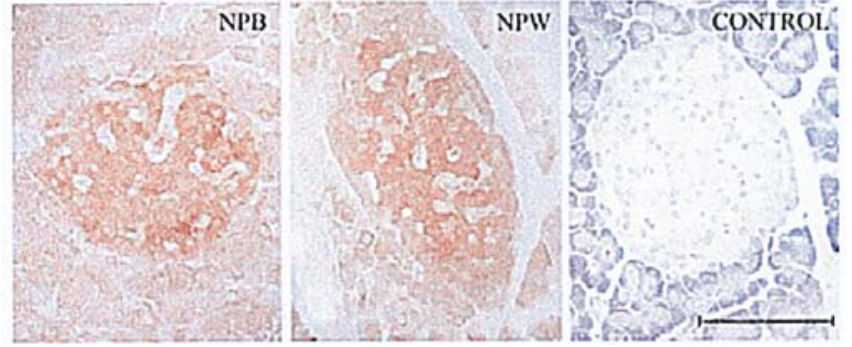

Figure 2. Localization of NPB- and NPW-like immunoreactivity in the rat pancreas. An intense immunohistochemical reaction for NPB and NPW was seen in all of the cells of the pancreatic islets while a less intense reaction was present in the cytoplasm of the pancreatic follicular cells. Magnification marked by bar, $100 \mu \mathrm{m}$.
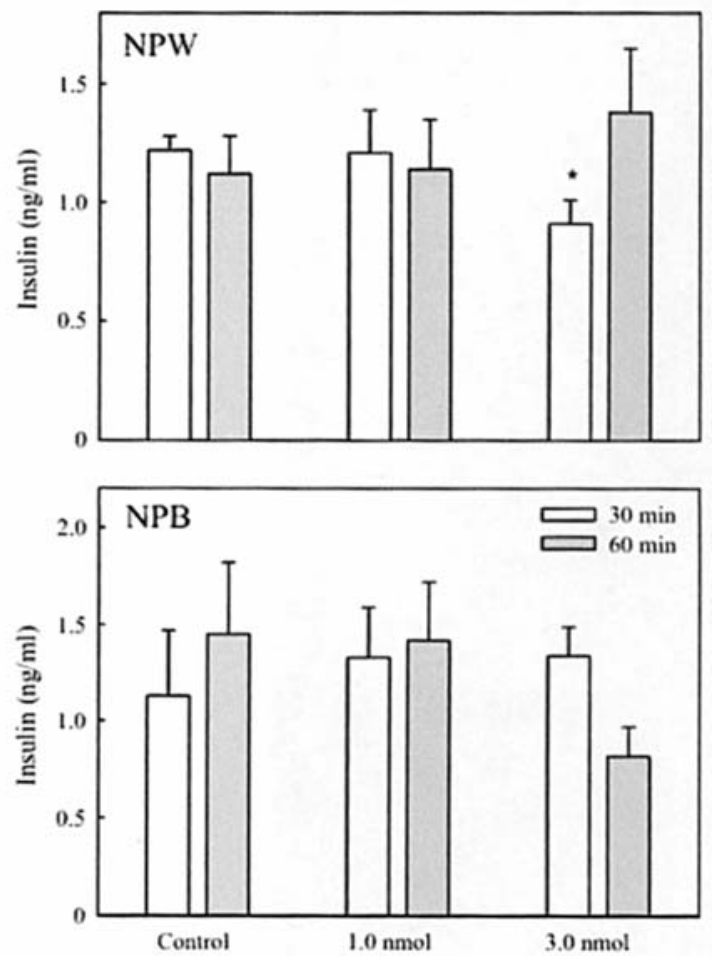

Figure 3. Acute effects of subcutaneous NPB or NPW injections at doses of 1 or $3 \mathrm{nmol} / 100 \mathrm{~g}$ body weight on blood insulin concentrations $(\mathrm{ng} / \mathrm{ml})$ of adult female rats at 30 and $60 \mathrm{~min}$ after neuropeptide administration. Bars represent means and SE is shown. Number of rats in each group, $n=7$. Statistical comparison of the data was performed by ANOVA followed by the multiple range test of Duncan; ${ }^{*} \mathrm{p}<0.05$ and ${ }^{* *} \mathrm{p}<0.01$ compared to the control group.

Peroxidase activity was detected using the DAB technique (Dako liquid DAB substrate-chromogen system, code no. K3466), and nuclei (when necessary) were counterstained with haematoxylin. Negative controls were carried out by similarly treating adjacent sections and omitting the primary antibody, as well as using primary antibody preabsorbed with antigen excess.

Insulin, leptin and glucose quantitation. Insulin and leptin in blood were assayed radioimmunologically using commercially available kits for rat insulin and leptin (Rat Insulin RIA kit, Rat Leptin RIA kit, Linco Research, Inc., St. Charles, MO,
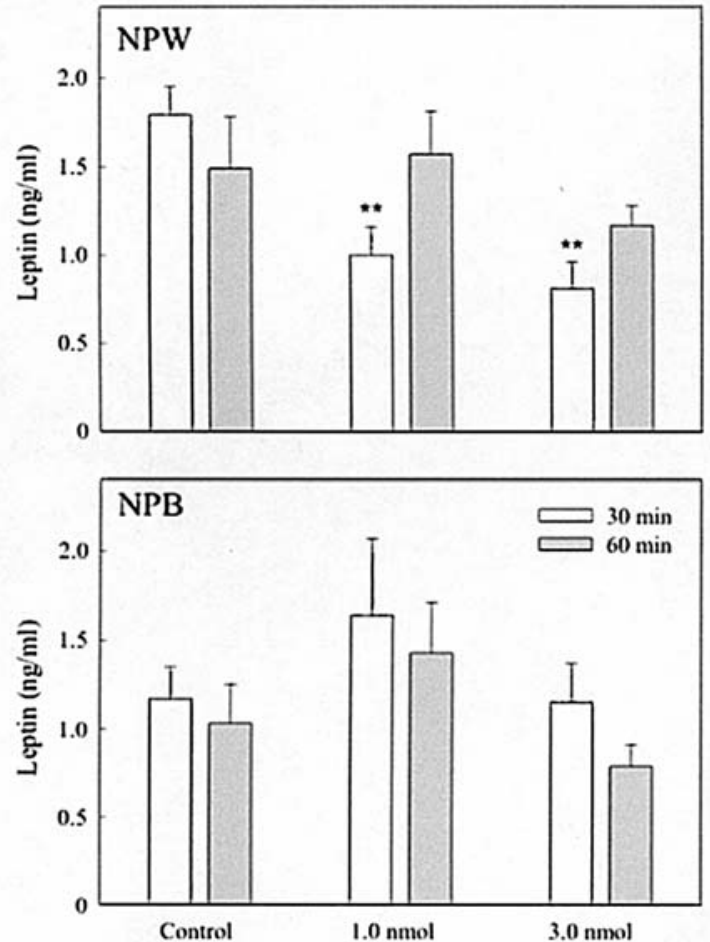

Figure 4. Acute effects of subcutaneous NPB or NPW injections at doses of 1 or $3 \mathrm{nmol} / 100 \mathrm{~g}$ body weight on blood leptin concentrations [ng/ml] of adult female rats at 30 and $60 \mathrm{~min}$ after neuropeptide administration. Bars represent means and SE is shown. Number of rats in each group, $n=7$. Statistical comparison of the data was performed by ANOVA followed by the multiple range test of Duncan; ${ }^{*} \mathrm{p}<0.05$ and ${ }^{* *} \mathrm{p}<0.01$ compared to the control group.

USA). Intraassay and interassay variations were 5\% and 7\%, respectively. Blood glucose concentrations were measured by the oxidase-peroxidase enzymatic method.

Statistics. Results were averaged per experimental group and \pm SE was calculated. Statistical comparison of the data was performed by ANOVA followed by the multiple range test of Duncan.

\section{Results}

RT-PCR technique revealed the presence of $p p N P B$, ppNPW, NPBWR1 and NPBWR2-like mRNAs in the isolated pancreatic islets of the rat (Fig. 1). With specific primers, RNA amplification (by means of RT-PCR) revealed the presence of reaction products with the expected sizes: NPB, 249 bp; NPW, 150 bp; and NPBWR1, 218 bp. This was similar to neuropeptide $\mathrm{B} / \mathrm{W}$ receptor $2,180 \mathrm{bp}$.

An intense immunohistochemical reaction for NPB and NPW was observed in all of the cells of the pancreatic islets while a less intense reaction was seen in the cytoplasm of the pancreatic follicular cells (Fig. 2). No reactions were noted in the corresponding control sections.

Only when a higher dose was administered ( $3 \mathrm{nmol} / 100 \mathrm{~g}$ body weight) did NPW transiently lower blood insulin levels in the studied rats while NPB injection did not alter insulinaemia in the studied rats (Fig. 3). At $30 \mathrm{~min}$ but not at 60 min after neuropeptide administration, NPW notably 

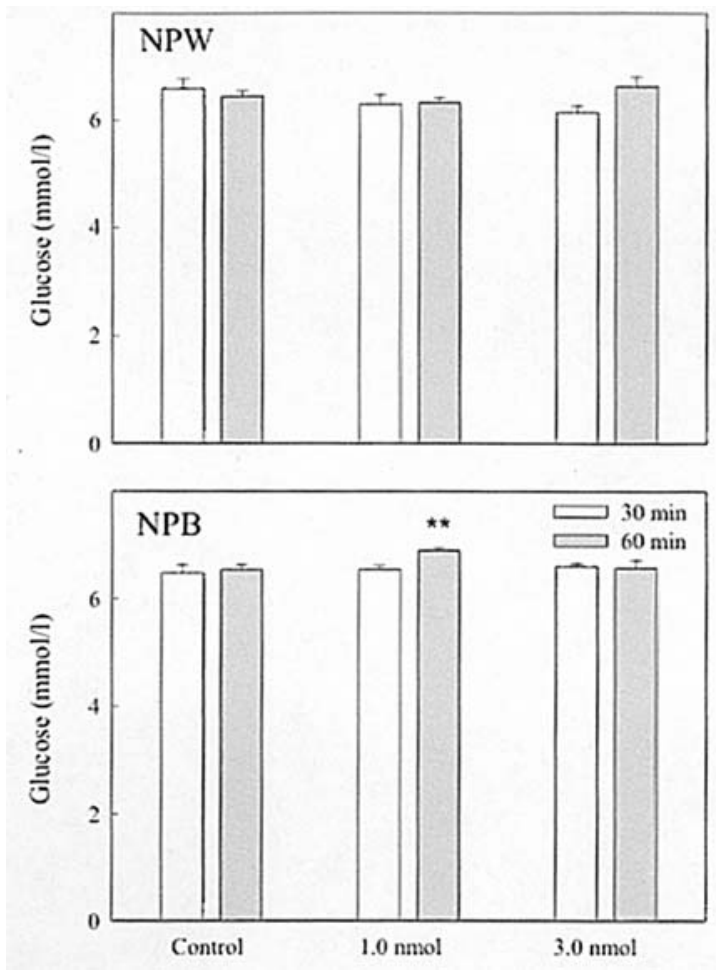

Figure 5. Acute effects of subcutaneous NPB or NPW injections at doses of 1 or $3 \mathrm{nmol} / 100 \mathrm{~g}$ body weight on blood glucose concentrations (nmol/l) of adult female rats at 30 and $60 \mathrm{~min}$ after neuropeptide administration. Bars represent means and $\mathrm{SE}$ is shown. Number of rats in each group, $\mathrm{n}=7$. Statistical comparison of the data was performed by ANOVA followed by the multiple range test of Duncan; ${ }^{*} \mathrm{p}<0.05$ and ${ }^{* *} \mathrm{p}<0.01$ compared to the control group.

lowered blood leptin concentrations in both tested doses without altering blood glucose concentrations (Figs. 4 and 5). Conversely, NPB injections had no effect on blood leptin concentrations. Only at $60 \mathrm{~min}$ after the injection of the lower neuropeptide dose ( $1 \mathrm{nmol} / 100 \mathrm{~g}$ body weight), were blood glucose concentrations higher when compared with the corresponding control rats.

\section{Discussion}

Both at the level of mRNA and protein, expression of NPB and NPW and their receptors in human and rat endocrine glands and hypothalamus have been well documented (6,16-21). Concerning the functional role of the NPB-NPW system, a growing body of evidence indicates that this system is involved in the regulation of neuroendocrine axis activity. This suggestion is confirmed by findings demonstrating that NPB or NPW evoked secretion of anterior pituitary and adrenocortical hormones in vivo $(5,10,18,20,22-24)$.

Physiological studies also demonstrated that NPB and NPW are involved in the regulation of energy homeostasis. Intracerebroventricular infusion of NPB in mice induced hyperphagia during the first $2 \mathrm{~h}$, followed by hypophagia (8). On the other hand, male NPBWR $1^{-/-}$mice developed adultonset obesity (7). NPB-deficient mice also manifested a mild, adult-onset obesity similar to that seen in NPBWR1-null mice (13). In addition, NPBWR1-null mice had decreased energy expenditure and locomotor activity, while their plasma levels of glucose, leptin, and insulin were elevated. These findings suggest that pancreatic islets are also involved in the development of obesity in NPB- and NPBWR1-deficient animals.

In the rat pancreas, all components of the NPB-NPW and their receptor systems have been found (19), and present studies have also confirmed our earlier observations on isolated pancreatic islets. As demonstrated, immunoreactivities for both neuropeptides were present in all of the cells of the islet, and pancreatic islet cells were also provided with their receptors. These findings suggest that both NPB and NPW affect pancreatic islet functions. In the present study, we demonstrated that an s.c. injection of the higher NPW dose lowered blood insulin concentrations within $30 \mathrm{~min}$. Moreover, both doses notably lowered blood leptin levels. This rather unexpected finding suggests that the primary effect of NPW on leptin secretion is to lower its level in general circulation. This effect may explain the findings of Tanaka et al (8) demonstrating NPB-induced hyperphagia within the first $2 \mathrm{~h}$ of the experiment, followed by hypophagia. On the other hand, Ishii et al (7) suggest that obesity in NPBWR $1^{-/}$mice is independent of leptin and melanocortin signaling. These observations of NPBWR1-deficient obese animals, however, provide proof of compensatory mechanisms occurring in such mice. Thus, our data suggest that the primary action of NPW on insulin and leptin secretion in the rat is an inhibitory one.

Unforeseeably, our results also revealed that, in contrast to NPW, NPB did not affect leptin and insulin concentrations in the rat. As known, both neuropeptides and their receptors are structurally highly homologous and this suggests that each ligand and receptor are partially overlapping and also have specific roles in this signaling system. As demonstrated, NPB activates and binds to both human NPBWR1 (with higher affinity) and NPBWR2, and similar effects are demonstrated with NPW23 and NPW30, with NPBWR1 binding with lower affinity $(6,8)$. Previous observations revealed notable differences in NPB and NPW action on both rat and human adrenocortical cells $(18,20,24)$. Present data on leptin and insulin regulation by NPB and NPW extend these earlier observations to include differences in the biological activity of both neuropeptides. Thus, similar localization of NPB and NPW and their receptors in endocrine glands and their partially overlapping function do not exclude their neuropeptide-specific action within the endocrine system.

Our findings on concomitant expression of NPB and NPW and their receptors in the pancreatic islets of the rat also suggest that both neuropeptides may paracrinally modulate biological functions of islet cells.

In conclusion, our results suggest that NPW but not NPB exerts a potent suppressive effect on blood leptin concentrations in the rat, and that this mechanism may be involved in the NPW regulation of energy homeostasis.

\section{References}

1. O'Dowd BF, Scheideler MA, Nguyen T, Cheng R, Rasmussen JS, Marchese A, Zastawny R, Heng HH, Tsui LC, Shi X, Asa S, Puy L and George SR: The cloning and chromosomal mapping of two novel human opioid-somatostatin-like receptor genes, GPR7 and GPR8, expressed in discrete areas of the brain. Genomics 28: 84-91, 1995. 
2. Lee DK, Nguyen T, Porter CA, Cheng R, George SR, Brian F and O'Dowd BF: Two related $G$ protein-coupled receptors: The distribution of GPR7 in rat brain and the absence of GPR8 in rodents. Mol Brain Res 71: 96-103, 1999.

3. Singh G and Davenport AP: Neuropeptide B and W: neurotransmitters in an emerging G-protein-coupled receptor system. Br J Pharmacol 148: 1033-1041, 2006.

4. Fujii R, Yoshida H, Fukusumi S, Habata Y, Hosoya M, Kawamata Y, Yano T, Hinuma S, Kitada Ch, Asami T, Mori M, Fujisawa $\mathrm{Y}$ and Fujino $\mathrm{M}$ : Identification of a neuropeptide modified with bromine as an endogenous ligand for GPR7. J Biol Chem 277: 34010-34016, 2002.

5. Shimomura Y, Harada M, Goto M, Sugo T, Matsumoto Y, Abe M, Watanabe T, Asami T, Kitada Ch, Mori M, Onda H and Fujino M: Identification of neuropeptide $\mathrm{W}$ as the endogenous ligand for orphan G-protein-coupled receptors GPR7 and GPR8. J Biol Chem 277: 35826-35832, 2002.

6. Brezillon S, Lannoy V, Franssen JD, Le Poul E, Dupriez V, Lucchetti J, Detheux M and Parmentier M: Identification of natural ligands for the orphan $\mathrm{G}$ protein-coupled receptors GPR7 and GPR8. J Biol Chem 278: 776-783, 2003.

7. Ishii M, Fei H and Friedman JM: Targeted disruption of GPR7, the endogenous receptor for neuropeptides $\mathrm{B}$ and $\mathrm{W}$, leads to metabolic defects and adult-onset obesity. Proc Natl Acad Sci USA 100: 10540-10545, 2003.

8. Tanaka H, Yoshida T, Miyamoto N, Motoike T, Kurosu H, Shibata K, Yamanaka A, Williams SC, Richardson JA, Tsujino N, Garry MG, Lerner MR, King DS, O'Dowd BF, Sakurai T and Yanagisawa M: Characterization of a family of endogenous neuropeptide ligands for the $G$ protein-coupled receptors GPR7 and GPR8. Proc Natl Acad Sci USA 100: 6251-6256, 2003.

9. Singh G, Maguire JJ, Kuc ER, Fidock M and Davenport AP: Identification and cellular localisation of $\mathrm{NPW}_{1}$ (GPR7) receptors for the novel neuropeptide $\mathrm{W}-23$ by $\left[{ }^{125} \mathrm{I}\right]-\mathrm{NPW}$ radioligand binding and immunocytochemistry. Brain Res 1017: 222-226, 2004.

10. Baker JR, Cardinal K, Bober C, Taylor MM and Samson WK: Neuropeptide W acts in the brain to control prolactin, corticosterone, and growth hormone release. Endocrinology 144: 2816-2821, 2003.

11. Mondal MS, Yamaguchi H, Date Y, Shimbara T, Toshinai Y, Shimomura Y, Mori M and Nakazato M: A role for neuropeptide $\mathrm{W}$ in the regulation of feeding behavior. Endocrinology 144: 4729-4733, 2003.

12. Levine AS, Winsky-Sommerer R, Huintron-Resendiz S, Grace MK and de Lecea L: Injection of neuropeptide $\mathrm{W}$ into paraventricular nucleus of hypothalamus increases food intake. Am J Physiol Regul Integr Comp Physiol 288: R1727-R1732, 2005.
13. Kelly MA, Beuckmann CT, Williams SC, Sinton CM, Motoike T, Richardson JA, Hammer RE, Garry MG and Yanagisawa M: Neuropeptide B-deficient mice demonstrate hyperalgesia in response to inflammatory pain. Proc Natl Acad Sci USA 102: 9942-9947, 2005.

14. Lacy PE and Kostianovsky M: Method for the isolation of intact islets of Langerhans from the rat pancreas. Diabetes 16: 35-39, 1967.

15. Ziolkowska A, Rucinski M, Di Liddo R, Nussdorfer GG and Malendowicz LK: Expression of the beacon gene in endocrine glands of the rat. Peptides 25: 133-137, 2004.

16. Dun SL, Brailoiu GC, Yang J, Chang JK and Dun NJ: Neuropeptide W-immunoreactivity in the hypothalamus and pituitary of the rat. Neurosci Lett 349: 71-74, 2003.

17. Dun SL, Brailoiu GC, Mizuo K, Yang J, Chang JK and Dun NJ: Neuropeptide B immunoreactivity in the central nervous system of the rat. Brain Res 1045: 157-163, 2005.

18. Hochol A, Albertin G, Nussdorfer GG, Spinazzi R, Ziolkowska A, Rucinski M and Malendowicz LK: Effects of neuropeptide B and $\mathrm{W}$ on the secretion and growth of rat adrenocortical cells. Int J Mol Med 14: 843-847, 2004.

19. Hochol A, Belloni AS, Rucinski M, Ziolkowska A, Di Liddo R, Nussdorfer GG and Malendowicz LK: Expression of neuropeptide $\mathrm{B}$ and $\mathrm{W}$ and their receptors in endocrine glands of the rat. Int J Mol Med 18: 1101-1106, 2006.

20. Mazzochi G, Rebuffat P, Ziolkowska A, Rossi GP, Malendowicz LK and Nussdorfer GG: G protein receptors 7 and 8 are expressed in human adrenocortical cells, and their endogenous ligands neuropeptides $\mathrm{B}$ and $\mathrm{W}$ enhance cortisol secretion by activating adenylate cyclase- and phospholipase Cdependent signaling cascades. J Clin Endocrinol Metab 90: 3466-3471, 2005.

21. Jackson VR, Lin SH, Wang Z, Nothacker HP and Civelli O: A study of the rat neuropeptide $\mathrm{B} /$ neuropeptide $\mathrm{W}$ system using in situ techniques. J Comp Neurol 497: 367-383, 2006.

22. Samson WK, Baker JR, Samson CK, Samson HW and Taylor MM: Central neuropeptide B administration activates stress hormone secretion and stimulates feeding in male rats. J Neuroendocrinol 16: 842-849, 2004.

23. Niimi $M$ and Murao K: Neuropeptide $W$ as a stress mediator in the hypothalamus. Endocrine 27: 51-54, 2005.

24. Andreis PG, Rucinski M, Neri G, Conconi MT, Petrelli L, Parnigotto PP, Malendowicz LK and Nussdorfer GG: Neuropeptides $\mathrm{B}$ and $\mathrm{W}$ enhance the growth of human adrenocortical carcinoma-derived NCI-H295 cells by exerting MAPK p42/ p44-mediated proliferogenic and antiapoptotic effects. Int J Mol Med 16: 1021-1028, 2005. 